\title{
Micro-culture and Macro-culture in urban housing architecture
}

\author{
Van Dung Le ${ }^{1,1}$ \\ ${ }^{1}$ University of Architecture Ho Chi Minh City (UAH), Pasteur str., 196, Ho Chi Minh City, Viet Nam
}

\begin{abstract}
In the era of information society, the development of urban housing architecture in the world has always associated with the tendency of cultural progress, localizing international architecture in parallel with internationalization of indigenous architecture, while still having a mixture of characteristics of oriental lifestyle with western lifestyle, and vice versa. The study allows determination of the form characteristics, and the mode of functional space organization of urban housing architecture corresponds to the two cultural types: Micro-culture of the East and Macro-culture of the West. This study forms the basis for preserving and recognizing the traditional essence of housing space between two relatively opposite cultures that exist throughout human history, especially in "flat world" conditions of postmodernity of the second half of the 20th and the 21th century.
\end{abstract}

\section{Introduction}

In the field of urban housing architecture, micro-culture and macro-culture still has not been studied as a system in order to distinguish the characteristics of living cultural organization between the East and the West. Although in terms of sociology and culturology, there has been more advance study of the differences in oriental and western lifestyles.

Research objects: characteristics of the form and method of organizing urban spaces in accordance with Eastern micro-culture and Western macro-cultural.

Research methods: analysis - comparative and dialectic of research results in the field of culture and urban housing theory (tendencies, schools, paradigms of social knowledge in housing architecture) to identify the characteristics of micro-macro culture in urban housing conditions.

Research targets: 1) determine the factors that originated the differences between microculture and macro-culture; 2) distinguish between synthetic thinking and analytic thinking in urban housing architecture; 3) identify schools and theories of housing architecture in the world conforming to micro-culture and macro-culture; 4) establish characteristics system of housing architecture that corresponding to Eastern culture and Western culture.

The concepts of Eastern and Western initiated by Europeans. "the West" is the European region where they reside (the North-Western region of the former Eurasia continent); the vast South-East region they have not known, including all of Asia and extending to Africa, are

\footnotetext{
${ }^{1}$ Corresponding author: zungle.ru@gmail.com
} 
called "the East". Thus, the East includes cross-border buffers zone from North-East Africa (including Egypt) to North-East of Eurasia continent to Siberian of Russia and downward to all the southlands (all of Asia, including South of Asia from India to China, Korea, Japan, and downward to Southeast Asia) [25].

Most of Eastern civilizations are in the tropical climate with settled agriculture lifestyles or wet rice farming. In contrast, Western civilizations are in cold temperate climate with nomadic lifestyles or wheat farming.

The concept of "micro-culture" or "micro-structure" (sub-structure) culture is a typical Eastern culture in which the socio-natural interaction systems in general and the social interaction system in particular is distinguished by two basic characteristics (signs): 1) the components (material and non-material) constitute the system which is mostly base components, available ; 2) the way in which the system operates (ie the program or rules of operating the system) is largely simple and one-dimension, toward retention, stability and adaptation.

The concept of "macro-culture" or "macro-structure"(great-structure) culture is a typical Western-style culture in which the socio-natural interaction systems in general and the social interaction system in particular is established and operated on two main platforms: 1) in addition to the available and basic components, the system is often replenished with the other nature-artificial elements; 2) the mode of operating system is complex, contains multidimensional specialized variable, characterized by innovative and extensive development.

\section{Literature review}

Micro-culture and macro-culture with urban housing architecture are considered based on the results of theoretical studies of culture in general and the main trends/schools in housing architecture in particular in the industrial stage (the last half of the 18 th century to the second half of the 20 th century) and the postindustrial period (the last half of the 20th century up to now) are presented in the following table (Table 1).

Table 1. Analytical and comparative table of studies related to micro-culture and macro-culture.

\begin{tabular}{|c|c|c|c|c|}
\hline \multicolumn{3}{|c|}{ Schools/theories of urban housing architecture in the world } & \multicolumn{2}{|c|}{ Relevance to } \\
\hline Author & $\begin{array}{c}\text { Main } \\
\text { concepts }\end{array}$ & $\begin{array}{l}\text { Key features related to micro-culture and } \\
\text { macro-culture }\end{array}$ & $\begin{array}{l}\text { Mic- } \\
\text { ro }\end{array}$ & $\begin{array}{l}\text { Mac- } \\
\text { ro }\end{array}$ \\
\hline \multirow{4}{*}{$\begin{array}{l}\text { Anisi-mov } \\
\text { L.Yu. } \\
{[1], 2009}\end{array}$} & \multirow{4}{*}{$\begin{array}{l}\text { Adapted } \\
\text { housing }\end{array}$} & Functional-technological re-equipment & 0 & \\
\hline & & Spatial expansion and development & $\bullet$ & $\bullet$ \\
\hline & & Merging/ dividing living quarters & Q & \\
\hline & & $\begin{array}{l}\text { Spatial variability (functional universality, } \\
\text { operational transformation, multifunctionality } \\
\text { of unified space) }\end{array}$ & Q & \\
\hline $\begin{array}{l}\text { Arake- } \\
\text { lianR.G. } \\
{[2], 2011}\end{array}$ & $\begin{array}{l}\text { Values of } \\
\text { traditional } \\
\text { housing }\end{array}$ & $\begin{array}{l}\text { Architectural and planning values: 1) low } \\
\text { degree of accessibility (irregular layout); 2) } \\
\text { transparency (pedestrian and visual } \\
\text { permeability); 3) autonomy of residential } \\
\text { clusters and units; 4) boundaries of } \\
\text { responsibility; 5) intensity and rational use of } \\
\text { territory (honeycomb structure, monolithic- } \\
\text { porous building structure, structure of } \\
\text { hierarchical order); 6) variety of visual } \\
\text { scenarios; 7) fractality of planning structure }\end{array}$ & 0 & 0 \\
\hline
\end{tabular}




\begin{tabular}{|c|c|c|c|c|}
\hline & & $\begin{array}{l}\text { Space-spatial values: 1) social and territorial } \\
\text { connection; 2) introversion; 3) architectural - } \\
\text { typological wealth; 4) variety of types of } \\
\text { functional elements; 5) scale; 6) adaptability }\end{array}$ & 0 & 0 \\
\hline \multirow{4}{*}{$\begin{array}{l}\text { BurlakovK.V. } \\
{[3], 2011}\end{array}$} & \multirow{4}{*}{$\begin{array}{l}\text { Topological } \\
\text { form-building } \\
\text { of } \\
\text { architecture }\end{array}$} & 1) non-linear form; 2) multiple function & 0 & \\
\hline & & $\begin{array}{l}\text { 3) dynamic;4) propensity to growth and } \\
\text { development }\end{array}$ & & 0 \\
\hline & & $\begin{array}{l}\text { 5) integrity and self-similarity of individual } \\
\text { parts and masses }\end{array}$ & 0 & $\circ$ \\
\hline & & 6) fractality & $\bullet$ & $\bullet$ \\
\hline \multirow{4}{*}{$\begin{array}{l}\text { Dada- } \\
\text { shevaM.M. } \\
\text { [4], } 2016\end{array}$} & \multirow{4}{*}{$\begin{array}{l}\text { Parametri- } \\
\text { cismof } \\
\text { architecture } \\
\text { (Digital } \\
\text { architecture) }\end{array}$} & Zoomorphic & 0 & $\bullet$ \\
\hline & & Atectonic chaos (effect "Fill form") & 0 & $\bullet$ \\
\hline & & Dematerialization of the architectural mass & 0 & o \\
\hline & & Ephemerality and absence of exteriorization & 0 & \\
\hline \multirow{3}{*}{$\begin{array}{l}\text { Denisen-ko } \\
\text { E.V. } \\
\text { [5], } 2013\end{array}$} & \multirow{3}{*}{$\begin{array}{l}\text { Bio approach } \\
\text { in housing } \\
\text { architecture }\end{array}$} & $\begin{array}{l}\text { Mimicry, metabolism, adaptation, } \\
\text { autoregulation, variability, self-healing }\end{array}$ & 0 & \\
\hline & & Discreteness, irritability & & 0 \\
\hline & & $\begin{array}{l}\text { Growth and development, energy exchanges, } \\
\text { reproduction, heredity, rhythmicity }\end{array}$ & $\bullet$ & $\bullet$ \\
\hline \multirow[t]{6}{*}{$\begin{array}{l}\text { Dob- } \\
\text { ritsynaI.A. } \\
{[6], 2004}\end{array}$} & \multirow[t]{6}{*}{$\begin{array}{l}\text { Nonlinear } \\
\text { architecture }\end{array}$} & $\begin{array}{l}\text { Architectural object as "field": space of } \\
\text { propagation and space of effects (speed, } \\
\text { connectedness of motion, "highest speed" } \\
\text { points) }\end{array}$ & & 0 \\
\hline & & Poetics without rules, poetics of uncertainty & 0 & \\
\hline & & Dialogic poetics & 0 & 0 \\
\hline & & Shapes - movement & 0 & o \\
\hline & & Electronic Baroque & & 0 \\
\hline & & The phenomenon of cyberspace & & 0 \\
\hline \multirow{3}{*}{$\begin{array}{l}\text { DutsevM.V. } \\
\text { [7], } 2014\end{array}$} & \multirow{3}{*}{$\begin{array}{l}\text { Architectural- } \\
\text { artistic object } \\
\text { as field }\end{array}$} & Space-time "field" & 0 & O \\
\hline & & Artistic "field" of integration & 0 & $\bullet$ \\
\hline & & Personal-individual "field" & & 0 \\
\hline \multirow[t]{3}{*}{$\begin{array}{l}\text { Fedchen-ko } \\
\text { I.G. } \\
\text { [8], } 2016\end{array}$} & \multirow[t]{3}{*}{$\begin{array}{l}\text { Principles of } \\
\text { formation of } \\
\text { residential } \\
\text { planning } \\
\text { units }\end{array}$} & $\begin{array}{l}\text { 1) accessibility of the material and spatial } \\
\text { environment of the microdistrict; 2) spatial, } \\
\text { socio-economic and virtual mobility; } 3 \text { ) } \\
\text { interaction of professional, social civic } \\
\text { groups;4) informational-opening policy of } \\
\text { planning }\end{array}$ & $\bullet$ & $\bullet$ \\
\hline & & $\begin{array}{l}\text { 5) differentiation; 6) identification of the } \\
\text { material-object and socio-cultural environment } \\
\text { of residence; 7) landscape-ecological worldview }\end{array}$ & & 0 \\
\hline & & 8) multi-functionality; 9) adaptability & 0 & \\
\hline $\begin{array}{l}\text { Ikonni- } \\
\text { kovA.V. } \\
{[9], 2002}\end{array}$ & $\begin{array}{l}\text { Anti- } \\
\text { architecture } \\
\text { (de architec- } \\
\text { ture) }\end{array}$ & $\begin{array}{l}\text { The form of housing architecture serves for } \\
\text { decoration or advertising by any method and } \\
\text { material to attract visual attention (the form } \\
\text { always is changedby context) } \rightarrow \text { Anti- } \\
\text { architecture as "Other architecture" }\end{array}$ & 0 & $\bullet$ \\
\hline \multirow{3}{*}{$\begin{array}{l}\text { Kiyanen- } \\
\text { koK.V. } \\
{[10], 2005}\end{array}$} & \multicolumn{2}{|c|}{ Paradigms of social knowledge inhousing architecture } & & \\
\hline & $\begin{array}{l}\text { Functional } \\
\text { paradigm }\end{array}$ & $\begin{array}{l}\text { 1) machine-housing for living;2)functional- } \\
\text { spatial system;3) place for activity;4) planning } \\
\text { normals;5) functional typology;6) standard } \\
\text { design; 7)order and hierarchy of functional } \\
\text { space;8) social housing }\end{array}$ & & 0 \\
\hline & $\begin{array}{l}\text { Interaction } \\
\text { paradigm }\end{array}$ & $\begin{array}{l}\text { 1) integration - segregation; 2) structure of } \\
\text { space "closedness - openness", "community - }\end{array}$ & 0 & O \\
\hline
\end{tabular}




\begin{tabular}{|c|c|c|c|c|}
\hline & & $\begin{array}{l}\text { independence"; } 3 \text { ) individual, group, collective } \\
\text { zones }\end{array}$ & & \\
\hline & & $\begin{array}{l}\text { 4) Cities - gardens;5) neighborhoods;6) houses - } \\
\text { communes; 7)multi-generational housing;8) } \\
\text { multifunctional housing;9) multifunctional } \\
\text { complex of housing }\end{array}$ & 0 & $\bullet$ \\
\hline & $\begin{array}{l}\text { Consume } \\
\text { paradigm }\end{array}$ & $\begin{array}{l}\text { 1) housing needs;2) housing standards;3) } \\
\text { cultural standards }\end{array}$ & $\bullet$ & 0 \\
\hline & & $\begin{array}{l}\text { 4) prefer space;5) housing quality;6) housing } \\
\text { market;7) commercial housing;8) different of } \\
\text { housing quality;9) profitable housing }\end{array}$ & & 0 \\
\hline & $\begin{array}{l}\text { Environ- } \\
\text { mental } \\
\text { paradigm }\end{array}$ & $\begin{array}{l}\text { 1) living environment;2) place of behavior; 3) } \\
\text { interpretability of housing; 4) content and } \\
\text { comfort of environment }\end{array}$ & & 0 \\
\hline & & $\begin{array}{l}\text { 5) architecture of complicity (democratic } \\
\text { architecture);6) core housing; 7)new urbanism }\end{array}$ & 0 & 0 \\
\hline & Phenomeno- & Totality of focusing properties of places & 0 & 0 \\
\hline & logical & Integrating past, present and future & 0 & 0 \\
\hline & & $\begin{array}{l}\text { Spirit of place and time (Genius Loci and } \\
\text { Zeitgeist) }\end{array}$ & 0 & $\circ$ \\
\hline & & Regional housing & 0 & 0 \\
\hline & & Traditional housing & 0 & 0 \\
\hline & & Phenomenology of housing & 0 & Q \\
\hline KulikovD.A. & Resource- & 1) Principle of localization, & 0 & \\
\hline$[11], 2011$ & & $\begin{array}{l}\text { 2) Principle of limitation; 3) principle of } \\
\text { specialization }\end{array}$ & & 0 \\
\hline & space & $\begin{array}{l}\text { 4) Principle of autonomy; 5) Principle of } \\
\text { hybridity; 6) Principle of structurality }\end{array}$ & 0 & 0 \\
\hline $\begin{array}{l}\text { Molcha- } \\
\text { novV.M. }\end{array}$ & $\begin{array}{l}\text { Socio- } \\
\text { functional }\end{array}$ & $\begin{array}{l}\text { Functional architecture: "Form follows } \\
\text { function" }\end{array}$ & & 0 \\
\hline [12], 2009 & $\begin{array}{l}\text { modeling in } \\
\text { architectural }\end{array}$ & $\begin{array}{l}\text { Environmental housing architecture: "Form } \\
\text { follows architectural and social environment" }\end{array}$ & 0 & 0 \\
\hline & design of & $\begin{array}{l}\text { Consume architecture: "Form follows } \\
\text { consuming" }\end{array}$ & $\circ$ & 0 \\
\hline & & $\begin{array}{l}\text { Phenomenological architecture: "Form follows } \\
\text { spirit of place and time(Genius Loci, Zeitgeist)" }\end{array}$ & 0 & 0 \\
\hline $\begin{array}{l}\text { OrelskaiaO.V. } \\
{[13], 2006}\end{array}$ & Eclecticism & $\begin{array}{l}\text { Combine elements of different artistic styles } \\
\text { into a architectural object }\end{array}$ & 0 & $\bullet$ \\
\hline & $\begin{array}{l}\text { Art deco in } \\
\text { architeture }\end{array}$ & $\begin{array}{l}\text { Focus on decorative objects with complex } \\
\text { varied types of architectural arts }\end{array}$ & & 0 \\
\hline & $\begin{array}{l}\text { Functiona- } \\
\text { lism }\end{array}$ & $\begin{array}{l}\text { Maintain fixed function at all levels of space: } \\
\text { from housing, housing complex to urban, } \\
\text { regional, as well as architectural forms }\end{array}$ & & 0 \\
\hline & $\begin{array}{l}\text { Organic } \\
\text { architeture }\end{array}$ & $\begin{array}{l}\text { 1. The housing space organization is always } \\
\text { based on the calculation of housing needs and } \\
\text { personal lifestyle of users/ consumers }\end{array}$ & 0 & 0 \\
\hline & & $\begin{array}{l}\text { 2. Unlimited using natural and local materials } \\
\text { 3. Maximum interaction with natural elements } \\
\text { and features (trees, water, climate, terrain) }\end{array}$ & 0 & $\circ$ \\
\hline & Brutalism & $\begin{array}{l}\text { - Refuse to decorate as much as possible } \\
\text { - Maintain the original integrity of building } \\
\text { material and structural details and even a } \\
\text { pipeline system in architectural form }\end{array}$ & 0 & \\
\hline
\end{tabular}




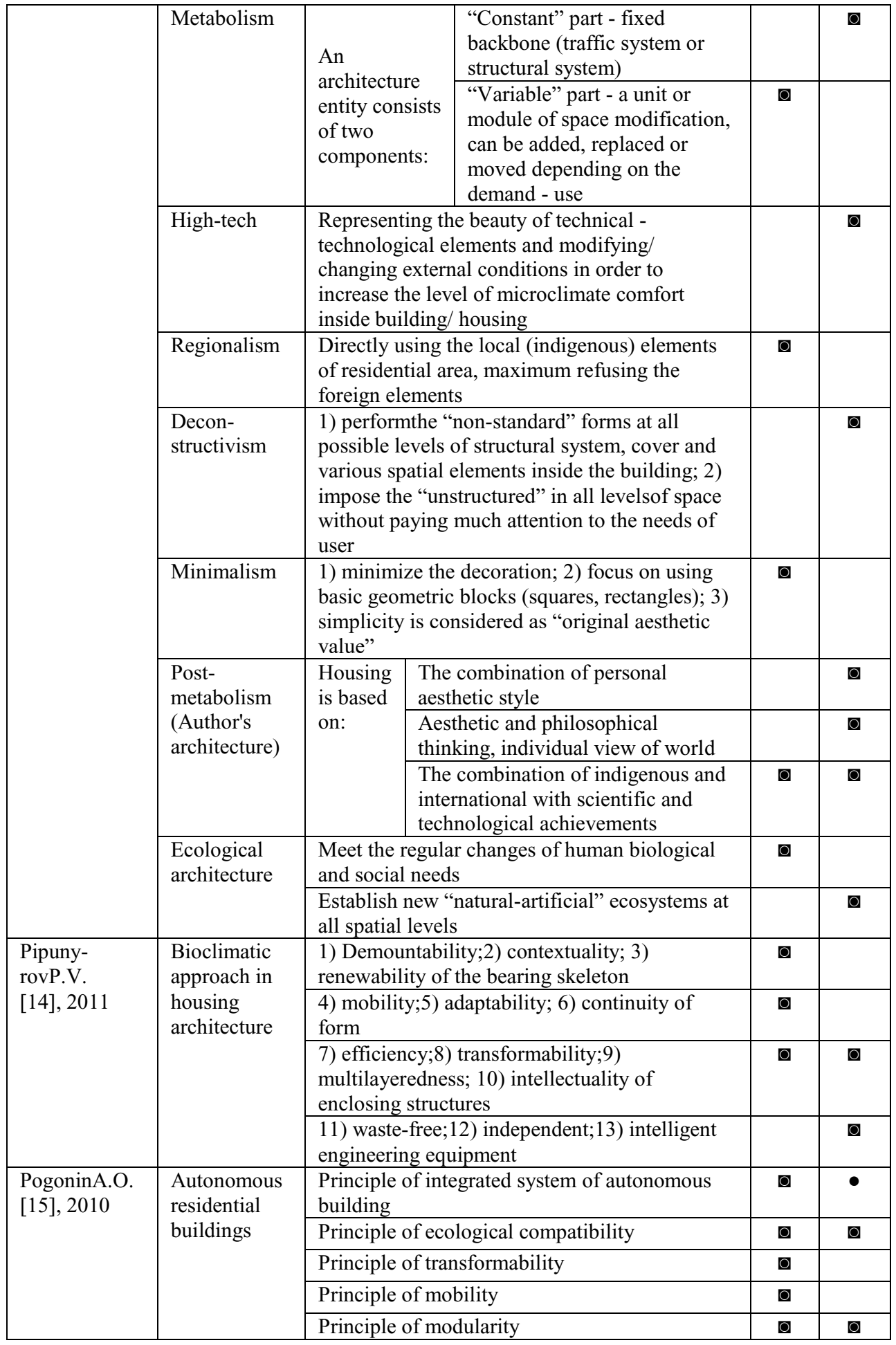




\begin{tabular}{|c|c|c|c|c|c|}
\hline $\begin{array}{l}\text { PutintsevP.A. } \\
{[16], 2011}\end{array}$ & Image of city & \multicolumn{2}{|c|}{$\begin{array}{l}\text { 6D (dimension) - Continuum (sight, smell, } \\
\text { touch, taste, hearing, vestibular apparatus) } \\
\text { asimage of city in the postindustrial social } \\
\text { information era }\end{array}$} & 0 & Q \\
\hline $\begin{array}{l}\text { Savelye-va } \\
\text { L.V. } \\
\text { [17], } 2016\end{array}$ & $\begin{array}{l}\text { Visual } \\
\text { illusions in } \\
\text { architectural } \\
\text { composition }\end{array}$ & \multicolumn{2}{|c|}{$\begin{array}{l}\text { 1) Depth, 2) Dynamic, 3) Geometric correction, } \\
\text { 4) Light effect, 5) Effect of disappearances }\end{array}$} & 0 & 0 \\
\hline \multirow{5}{*}{$\begin{array}{l}\text { Vershi-nin } \\
\text { G.V. } \\
{[18], 2005}\end{array}$} & \multirow{5}{*}{$\begin{array}{l}\text { Context in } \\
\text { architecture, } \\
\text { design and art }\end{array}$} & \multicolumn{2}{|c|}{ 1) Natural context } & 0 & \\
\hline & & \multicolumn{2}{|c|}{ 2) Social context } & 0 & $\circ$ \\
\hline & & \multicolumn{2}{|c|}{ 3) Temporary context } & 0 & \\
\hline & & \multicolumn{2}{|c|}{ 4) Personal context } & & Q \\
\hline & & \multicolumn{2}{|c|}{ 5) Creative context } & & 0 \\
\hline \multirow[t]{6}{*}{$\begin{array}{l}\text { VoroninaA.V. } \\
{[19], 2012}\end{array}$} & \multirow[t]{6}{*}{$\begin{array}{l}\text { Eco-re- } \\
\text { urbanization }\end{array}$} & \multirow{6}{*}{$\begin{array}{l}\text { Models of } \\
\text { eco-re- } \\
\text { urbanization }\end{array}$} & $\begin{array}{l}\text { Ecology as a new design } \\
\text { ideology }\end{array}$ & 0 & Q \\
\hline & & & City-area & & 品 \\
\hline & & & City as ecosystem & $\bullet$ & D \\
\hline & & & Landscape as infrastructure & 0 & Q \\
\hline & & & $\begin{array}{l}\text { Neo-nature: new forms of } \\
\text { nature }\end{array}$ & & Q \\
\hline & & & Re-, secondary action & & Q \\
\hline $\begin{array}{l}\text { Vytuleva } \\
\text { K.O. } \\
\text { [20], } 2010\end{array}$ & $\begin{array}{l}\text { New images } \\
\text { of the newest } \\
\text { architecture }\end{array}$ & \multicolumn{2}{|c|}{$\begin{array}{l}\text { 1) architecture increasingly resorts to the } \\
\text { representation ("replacing images with a } \\
\text { signs"); 2) buildings as analogue of the design } \\
\text { logo; 3) facades as screens, skin, interface; 4) } \\
\text { effect of "flicker" of architectural image }\end{array}$} & 0 & 0 \\
\hline \multirow{9}{*}{$\begin{array}{l}\text { ZaitsevA.A. } \\
{[21], 2013}\end{array}$} & \multirow{9}{*}{$\begin{array}{l}\text { Contex- } \\
\text { tualism as } \\
\text { style of } \\
\text { architecture }\end{array}$} & \multicolumn{2}{|c|}{ Compositional contextualism } & $\bullet$ & 目 \\
\hline & & \multicolumn{2}{|c|}{ Historical contextualism } & 0 & Q \\
\hline & & \multicolumn{2}{|c|}{ Stylistic contextualism } & & Q \\
\hline & & \multicolumn{2}{|c|}{ Regional (traditional) contextualism } & 0 & \\
\hline & & \multicolumn{2}{|c|}{ Ornamental and decorative contextualism } & 0 & Q \\
\hline & & \multicolumn{2}{|c|}{ Structural-morphological contextualism } & 0 & 0 \\
\hline & & \multicolumn{2}{|c|}{ Figurative-symbolic contextualism } & 0 & Q \\
\hline & & \multicolumn{2}{|c|}{ Typological contextualism } & 0 & 0 \\
\hline & & \multicolumn{2}{|c|}{ Architectural-tectonic contextualism } & 0 & Q \\
\hline $\begin{array}{l}\text { Zaslavs- } \\
\text { kaiaA.Yu. } \\
{[22], 2008}\end{array}$ & $\begin{array}{l}\text { Organic } \\
\text { approach in } \\
\text { housing } \\
\text { architecture }\end{array}$ & \multicolumn{2}{|c|}{$\begin{array}{l}\text { Models of shaping: pockets, bubbles, bend, } \\
\text { flowers, strands, pattern, skin, teeth, branch, } \\
\text { streaks }\end{array}$} & $\bullet$ & $\bullet$ \\
\hline \multirow[t]{2}{*}{$\begin{array}{l}\text { Zhda-nova } \\
\text { I.V. } \\
{[23], 2013}\end{array}$} & $\begin{array}{l}\text { Consumer } \\
\text { properties of } \\
\text { residential } \\
\text { environ- }\end{array}$ & \multicolumn{2}{|c|}{$\begin{array}{l}\text { Method of functional improvement } \\
\text { Method of ergonomic improvement } \\
\text { Method of engineering and technical } \\
\text { improvement }\end{array}$} & & 0 \\
\hline & ments & \multicolumn{2}{|c|}{$\begin{array}{l}\text { Method of ecological improvement } \\
\text { Method of Aesthetic improvement }\end{array}$} & $\bullet$ & 0 \\
\hline $\begin{array}{l}\text { Nguyen S. } \\
\text { Hoan Nguyen } \\
{[24], 2016}\end{array}$ & $\begin{array}{l}\text { Cultural } \\
\text { value level in } \\
\text { housing } \\
\text { architecture }\end{array}$ & \multicolumn{2}{|c|}{$\begin{array}{l}\text { Flexibility and versatility of housing space } \\
\text { by level of needs } \\
\text { - Harmony with nature of housing space by } \\
\text { level of needs } \\
\text { - Traditionalprivatizationof housing space by } \\
\text { level of needs }\end{array}$} & 0 & o \\
\hline
\end{tabular}




\begin{tabular}{|l|l|l|c|c|}
\hline Tran Ngoc & $\begin{array}{l}\text { Spiritual } \\
\text { culture }\end{array}$ & Social statics & $\mathbf{0}$ & \\
\cline { 2 - 5 } \begin{tabular}{l} 
[25],2006 \\
\cline { 2 - 5 }
\end{tabular} & $\begin{array}{l}\text { Civilization } \\
\text { (material } \\
\text { culture) }\end{array}$ & Social dynamics & & $\mathbf{0}$ \\
\hline
\end{tabular}

Note: ם more related; $\bullet$ average related; $\circ$ less related

\section{Materials and methods}

Boundary of micro-culture and macro-culture territories as follows (Fig. 1).

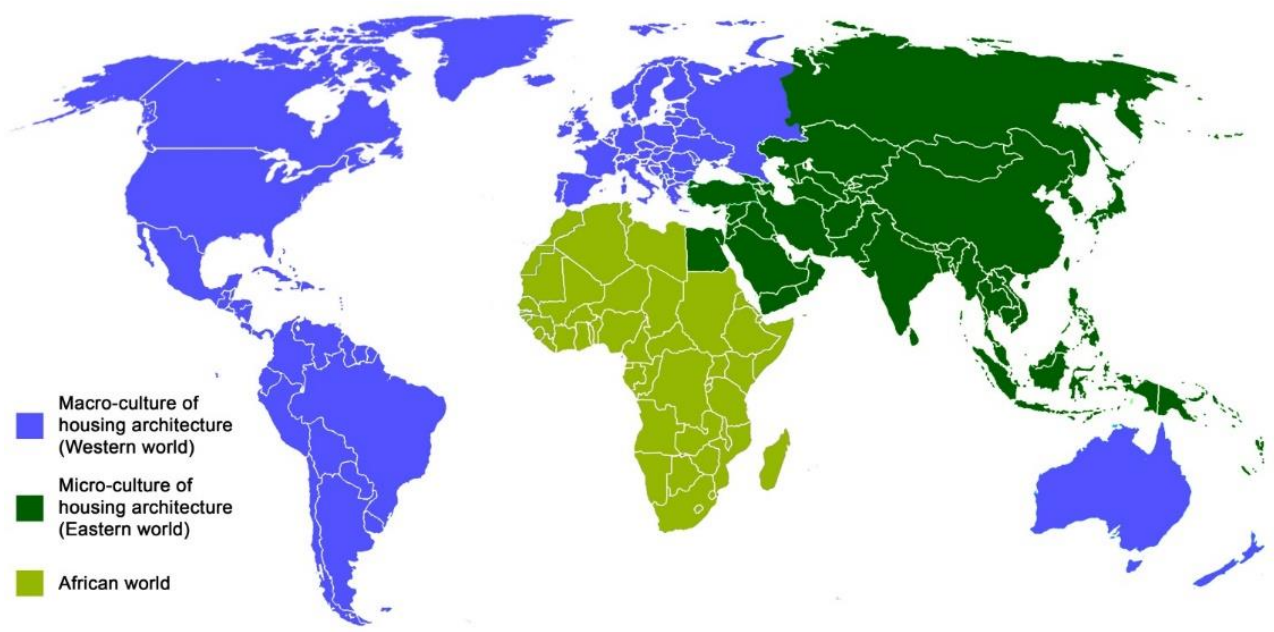

Fig. 1. Boundary of micro-culture and macro-culture territories.

Oriental culture (including Vietnamese) originates from short - term seasonal paddy agriculture foundation which is static and permanent.

As the external environment is a continuous cycle, the ability to cope with the influences of the Easterners is relatively mobile and flexible. However, the cyclicality of external influences has almost unchanged for many thousand years of history that has degraded the dynamic mind and active think (intellectual development) of Easterners, making them almost live up to the habitual reaction and customized habits.They don't like the change and highly appreciate the importance of settlement, security, long-term stability. On the other hand, they are very easy to change themselves to adapt to the environment immediately. These attributes create many advantages of cultural lifestyle: harmonization, maintenance, preservation and high self-defense. This includes the short-term adaptive capacity (tactical feature) as well as the ability to react immediately to the environment is relatively fast, effective and timely. It is very easy to change itself for temporary response that has formed the character of acceptability in order to fit in with the external influences of Eastern culture.

This adaptation (rather than development) of settled agriculture has contributed to the establishment of a traditional specific Eastern culture - the "substructure" (or micro-structure) which is present in all areas of socio-natural interaction. Large, complex social and natural structures or systems are difficult to absorb (not to mention higher levels of consumption), because they are almost unsuited to the dynamic adaptation particulars as well as the ready acceptability, easy changing of oriental lifestyles.

In addition, the self-regulating capacity of the traditional smallholder economy, when an individual agricultural unit (household economy) can self-sustain through the closed production process of the "garden - pond - barn" also contribute to the "micro-structure" in 
socio-cultural interaction. Thanks to the form of sub-agricultural production that can supply itself with the most basic requirements for long-term viable survival, has established a strong supportive system, and based on which the inhabitants of traditional oriental agriculture have almost no need to develop into more complex economic production systems of the form of "great structure" (or macro-structure). The typical examples of "substructures" in traditional oriental agricultural societies can be mentioned as: 1) sub-urban culture in traditional craft villages and cities; 2) sub-commercial system (or economic culture of small retailers along roads, pavements); 3) the "sub-natural" system of housing architecture, such as: small landscape art, decorative water surface in housing yard, small lotus pond, aquarium, closed united socio-economic space "yard - garden - pond/ lake" on a small scale in the traditional rural house.

One more the specific features of traditional Eastern culture is the ability to think in terms of aggregation/ synthetic - the way of life is greatly influenced by the combination of multi forms of versatile agricultural production of settled agricultural residents. A traditional unit of agricultural economics (individual and household) can simultaneously undertake various functions (works) at the same time: 1) small farmers (it should be emphasized that small farmers are small agri-multi component and versatile, not single-component, including: fruit trees, growing vegetables, farming, raising fish, raising cattle); 2) small traders (most of whom trade in agricultural products) and 3) handicrafts (agricultural produce, pottery, weaving, tanning, etc.).

Moreover, the "innate" capacity for aggregate thinking is also a product of Eastern culture. Because the culture itself is almost not a monotonous nature, it belongs to the multicultural combination of cultures (cultural diversity) through the regularly cultural exchange process between regions. To put it more precisely, with a specific characteristic that is easily receptive, quick to change just to adapt in a conventional "instinct" manner so traditional oriental farmers can reconcile any other traditional system that is thought to be appropriate for the needs of leisurely "career" instincts (again emphasize the "instinct"!) and simple living demands. It is this multifaceted, multifunctional thinking style of the Orient that creates the basis for the activation of the traditional way of organizing space as follows: varied functions in the same space of uniform use.In the case of necessary to expand area of housing use in order to satisfy the continuous increasing in the quantity of members of agricultural production, traditional agricultural residents often choose two solutions: 1) build and add new small living space units next to main house (additional outhouses) in the form of linking small structures in a large multi-group of housing space (the interactive way of medium and high income agricultural households). This is also an expression of the cultural characteristics of the "substructure" ("small dispersed culture") in spatial organization of Eastern tradition; 2) dynamically divide the available spaces into a unified integrated multifunctional mobile space in the form of movable multifunctional partitions in one space (the interactive way of low income agricultural households).

Nearly the opposite of the temperate paddy culture, Western culture derives from dry nomadic agriculture that is dynamic and moving, prone to repressive power and tyranny.

If the agricultural culture of wet rice farming is very important in the number of manpower for agricultural production, then the dry agricultural culture (nomadic farming and wheat agriculture) places more emphasis on the real role/ ability of manpower - individual. To put it succinctly, the nomadic culture is characterized by the keyword "quality" while agricultural culture settles on the keyword "quantity".

This kind of "respecting the strength" culture (or main - minor culture) promotes the ability of individual "I", asserting personal power in the community so that the social interactions of nomadic farming populations often carry high character, difficult to change itself, difficult to accept. Therefore, the capacity to cope with changes in the external context of the nomadic population is also relatively slow, not as flexible as that of agricultural 
dwellers settling in paddy fields. This is also the main reason for constituting the way of socio-natural interaction of Westerners, that they focus more on strategy, long-term problems in order to change external conditions (because it is difficult to modify themselves), as well as through large/ great and grandiose forms for expressing the ability to "impose and change everything". For example: large architectural ensembles in ancient capitals and the castles with the majestic dimensions of space of Europe.

This long-standing strategic culture has contributed to the developing character-centered attitude toward outdoor character analysis (aimed at changing the external environment to establish and improve self-empowerment and self-control) of the original nomadic population. This behavior plays a role as the catalyst factor in forming the traditional way of organizing traditional space of dry agricultural inhabitants: the tendency to analyze the origin of spatial function and divide specialized functional space components in housing. For example, "fixed-functional separate multiroom" housing model has two yards "Peristyle + Atrium" (Pompey, 1st century BC). Significantly, this type of housing is also a concrete manifestation of the thinking of emphasizing form's expression, the "great form" and "macro, great structuralization". If the house of paddy farmers always tends to disperse small space components (in the form of multi space partition) or establish multi-functional synthesis (mixed-use structures) in one space, then the housing of Western nomadic residents is more logically organized as a unified ensemble of specialized functional separate spaces (combining specialized spaces/ rooms into a unified multi-functional complex).

It is no coincidence that almost every architectural system/ movement specialized in function or expression of architectural sciences originates in Europe (such as the trend "Functionalism" of the 20th century, the classic column system of Greece, Rome, the architectural style of Gothic grandiose decoration, etc.). Because formality and functional specialization (similar to the capacity to divide power and strengh) are attributes of the social instinct (instinctive power), which exist as original code are available in the cultural characteristics of nomadic inhabitants.

The tradition of highly appreciating the value of "personal quality" (individualism) of nomadic people - dry agriculture is also seen as a major catalyst in forming the habit of distinguishing "primary - secondary" (main - minor, main - sub) and distinctiveness (the "itself must be exceptional") of the West. On the contrary, the forte for "personal quantity" (collectivism) of rural paddy farmers creates a source of impetus that forms the characteristic "harmony" of the oriental identity. The space of the housing architecture in particular and the architecture in general are thus also distinguished into two different viewpoint "schools" of forming and organizing space: the West is inclined to the separation of "main or minor space" or specific spaces (affirming distinctive values or individual symbols), and the Orient often follows the establishing "types of harmonic space" (polysemy of function and harmony of "all in one").

Importantly, in essence, Western culture can be considered in the "Macro-structure" or Macro-oriented cultural model, through typical systems such as the macro-culture of commerce - service. The culture of "macro commerce" (economic culture of a large scale and structure) appeared very early in the ancient European cities, and many of them belonged to the large family's economic model - clan's economic system (production of silk, ceramics, olive oil, agriculture - seafood, salt trade, jewels, pawns, banks, etc.). Later capitalist economic models also derive from these "great structures" economic forms. This is one of the most specific expression of the culture of "individual strength" and the regularity of reinforcing the private power of western nomadic residents. For example, settled agricultural inhabitants are inclined to "sub-natural" in architecture, dry nomadic populations follow the tendency of establishing large ensembles of natural elements or "artificial nature" in architecture. 
Thus, the most important distinctions between Western-style traditional cultural interaction (featured by power) and traditional Eastern culture (featured by harmony) are in the four-dimensional reference coordinate system as follows.

- first dimension (X axis) - worldview thinking "axis". If Western thinking is specialized (analytical) and monotonic/ monofunction in style $1=0.5+0.5$, or $1=0.1+0.9$, ... (ie focus on deep analysis of the original nature of number " 1 " in order to understand purpose of number " 1 " and control him), and A = A (specific A and A can only be A),then the Orient pronzes to synthetic and multifunction in style $0.5+0.5=1$, or $0.1+0.9=1, \ldots$ (synthesized to form number " 1 "and not necessary to understand nature of number "1"), and $\mathrm{A}=\mathrm{A}$; $\mathrm{A}$ ”; A1; A2; ... (A multi-function and A has many variations);

- second dimension (Y axis) - "axis" of method of socio-natural interaction. If the West pronzes to the question "Why?" in almost every socio-natural interaction for modifying or denying (unaccepting) the influence of the external environment, then the East pronzes to "acceptance"("no question") to be consistent with the impact of external environmental factors without necessarily understanding the nature or rules or understanding of how the external environment acts in style "By the mandate of heaven" or "Right place (follows nature), right time and right person";

- third dimension (Z axis)-“axis"of the structural characteristics of original cultural system. If the Western cultural structure characterized by "self control of each thing" cares about rules,order, logic and absolutism, then the Orient is in favor of the manner of "transformation of everything" caring about incidental, romantic, metabolism and relativism;

- fourth dimension ( $\mathrm{T}$ axis) - "axis" of consequent reaction in process of cultural interaction. Process absolutism of the West generates relative and exceptional effects in the form of active democratism (it means that, every thing can be changed in necessary conditions).In other words, active Democratism $=$ Absolutism + its opposing reactive effects (Relativism and Exceptionalism). Similarly, for the East: passiveNonlinear $=$ Relativism + its "impulsive" reactive effects (Modularization+ Copy (mimicry)).Thus, active Democratism and passive Nonlinear can be correspondingly considered as the main fundamentalfeatures of Western and Orientalcultures in general and housing architectures in particular.

This traditional "constant entity" or "original code" creates opposite distinction in most traditional cultural and social systems between the East and the West, not just in the past of the traditional agricultural society era but also throughout the later industrial and postindustrial social epochs.

Table 2. The difference between the "substructure" architectural culture (micro-culture) and "great structure" architectural culture (macro-culture).

\begin{tabular}{|c|c|}
\hline $\begin{array}{c}\text { Micro-culture } \\
\text { ("substructure"/ "micro-structure" culture) }\end{array}$ & $\begin{array}{c}\text { Macro-culture } \\
\text { ("great structure"/ "macro-structure" culture) }\end{array}$ \\
\hline \multicolumn{2}{|c|}{ Main culture characteristics } \\
\hline $\begin{array}{l}\text { Synthetic multi-function, multi-variant } \\
\text { pronzes to small system and structure(type: A } \\
=\text { A'; A"; A1; A2) }\end{array}$ & $\begin{array}{l}\text { Analytic (separative) monopoly, monofunction } \\
\text { pronzes to large systems and structures(type: } A= \\
\text { A (A can only be A)) }\end{array}$ \\
\hline $\begin{array}{l}\text { Synthetic, simple, in the usual style: } 0.1+ \\
0.9=1 ; \text { or } 0.5+0.5=1 ; \ldots \text { ("All in one" style) }\end{array}$ & $\begin{array}{l}\text { Analytic, specialized, in the usual style: } 1=0.1+ \\
0.9 \text {; or } 1=5-4 \text {; or } 1=2 / 2 ; \ldots \text { ("One and all the } \\
\text { rest" style) }\end{array}$ \\
\hline $\begin{array}{l}\text { Harmonyand polysemy: } \\
\mathrm{B}+\mathrm{C}+\mathrm{D}=\mathrm{A} \text {; or } \mathrm{C}+\mathrm{X}+\mathrm{M}=\mathrm{A} \text {; } \\
\mathrm{A}, \mathrm{B}, \mathrm{C}, \ldots \text { are the same or similar }\end{array}$ & $\begin{array}{l}\text { Main - sub anddistinctiveness: } \\
\text { AcLm£6y0 Щ }\end{array}$ \\
\hline $\begin{array}{l}\text { The typical question: no question, "How } \\
\text { much?" } \\
\text { The typical answer: "Yes!" }\end{array}$ & $\begin{array}{l}\text { The typical question: "Why?", "Whose?" } \\
\text { The typical answer: "No!" } \\
\text { The typical problems: frequency - intensity, } \\
\text { general - private }\end{array}$ \\
\hline
\end{tabular}




\begin{tabular}{|l|l|}
\hline $\begin{array}{l}\text { The typical interested problems: fast - slow, } \\
\text { many - few }\end{array}$ & \\
\hline $\begin{array}{l}\text { "Transformation of everything": metabolism, } \\
\text { incidental, saltation, disorder }\end{array}$ & $\begin{array}{l}\text { "Self control of each thing": self-regulation, self- } \\
\text { operation, imposition, rule }\end{array}$ \\
\hline
\end{tabular}

\begin{tabular}{|c|c|}
\hline \multicolumn{2}{|c|}{ The traditional way of socio-naturalinteraction } \\
\hline $\begin{array}{l}\text { Relativism as primary feature of socio-natural } \\
\text { interaction } \\
\text { Modularizationand Copy as secondary } \\
\text { features }\end{array}$ & $\begin{array}{l}\text { Absolutism as primary feature of socio-natural } \\
\text { interaction } \\
\text { Relativism and Exceptionalism as secondary } \\
\text { features }\end{array}$ \\
\hline Prone to static, placidity and tactics & Prone to dynamic, strength and strategy \\
\hline Caring about storage and stablization & The tendency to change, to develop creatively \\
\hline Trend fits with nature & Trend improves and changes nature \\
\hline Prone to community and ambiguity & Prone to individual and boundary \\
\hline Hiding and sensitivity & Expression and rationality \\
\hline $\begin{array}{l}\text { "One for all" (one starting from reference } \\
\text { system - "origin-all") style }\end{array}$ & $\begin{array}{l}\text { "All for one" (all starting from reference system } \\
\text { - "origin-one") style }\end{array}$ \\
\hline $\begin{array}{l}\text { Passive in mind but the ability to deal with } \\
\text { mobility and flexibility before external } \\
\text { changes }\end{array}$ & $\begin{array}{l}\text { Active in mind but the ability to deal with slowly } \\
\text { before external changes }\end{array}$ \\
\hline Easy to be changed, easy to receive & Difficult to change, difficult to receive \\
\hline Prone to past (traditional) and present values & Prone to present and future values \\
\hline $\begin{array}{l}\text { Theory is not necessarily compatible with } \\
\text { facts }\end{array}$ & Theories and facts must be compatible \\
\hline
\end{tabular}

Traditional expressing the form and organization of architectural space

Sub-form: prone to small form and size. The rate of housing architecture harmonizes with human

Proning to synthesis and combining of spatial functions (or mobility in spatial organization): the spatial housing structure is often multifunction in one space and dynamically transformingfunctional spaces to simultaneously serve multiple needs

Versatile characteristics, synthesis of multi space partition in a space

$\rightarrow$ Set up space in the direction of adaptive mobility and maximum flexibility to the external environment: focus on the use of protection elements and movable partitions on the basis of dynamic, compact, flexibility

\section{Space "harmony":}

- a space that harmonizes as many different functions as possible;

- a space may be specialized functional but does not focus on importance of any usable space.
Great form: prone to large, massive form and size. The rate of unbalance (separation, segregation) is high

Proning to analysis of the origin of spatial functions (or fixedness in spatial organization): focus on the specialized division of functions of spatial components in housing to meet the specialized demand/ needs of livers

Monotonic characteristics, specializedfixedfunctional spaces in unified complex $\rightarrow$ Set up living space in a way that is separated from the external environment or to modify the environment in order to increase the comfort level of microclimate: prone to fixedpositioning or regulating specialized function of components and elements for protecting the housing space

"Main - sub" space and unique - specialized space:

- main space: individual comfort space which expresses and affirms "I" individual; subspace: remaining spaces, including common community space;

- unique - specialized space: space for individual "I" with unique creativity, characterizes by the "I" way of living that this individual is not repeated in other "I" individual.

The typical traditional socio-natural interaction systems in housing architecture 


\begin{tabular}{|l|l|}
\hline $\begin{array}{l}\text { "Open architecture" culture: prone to } \\
\text { maximum direct communication (integration) } \\
\text { between housing and the external } \\
\text { environment. }\end{array}$ & $\begin{array}{l}\text { The "closed architecture" culture: prone to } \\
\text { maximum isolation(segregation) of housing with } \\
\text { the external environment. }\end{array}$ \\
\hline $\begin{array}{l}\text { Suburban culture and Sub-commercial - } \\
\text { service culture in the living environment. }\end{array}$ & $\begin{array}{l}\text { The great urban culture and Great commercial - } \\
\text { service culture in the living environment }\end{array}$ \\
\hline Culture "Sub-nature" in architecture. & $\begin{array}{l}\text { Culture "great natural- artificial massif and great } \\
\text { natural massif" in architecture. }\end{array}$ \\
\hline $\begin{array}{l}\text { Organization of micro-architecture: housing } \\
\text { as 1) a dispersal of multi-functional } \\
\text { components or 2) a synthesis of multi space } \\
\text { partition in one space }\end{array}$ & $\begin{array}{l}\text { Organization of macro-architecture: housing as a } \\
\text { large specialized multi-functional complex/ } \\
\text { ensemble (a large-scale complex) }\end{array}$ \\
\hline
\end{tabular}

Thus, the architectural characteristics of housing correspond to the two world views: the "synthetic thinking" of theEast and the "analytic thinking"of the West as follows (Table3).

Table 3. Specific featuresof urban housing architecture.

\begin{tabular}{|c|c|}
\hline $\begin{array}{c}\text { Synthetic thinking } \\
\text { (Specific features of the Oriental) }\end{array}$ & $\begin{array}{c}\text { Analytic thinking } \\
\text { (Specific features of the Western) }\end{array}$ \\
\hline $\begin{array}{l}\text { Integration of different functional spaces/forms } \\
\text { component into a composite system (discrete } \\
\text { complex of many small components) }\end{array}$ & $\begin{array}{l}\text { Organizing functional spaces and forms in the } \\
\text { direction of isolating each element into a } \\
\text { separativefunctional unit and grouping it into a } \\
\text { large system (the logical alliance of many big } \\
\text { single uniform elements) }\end{array}$ \\
\hline $\begin{array}{l}\text { Ignoring the complex interactive relationship } \\
\text { between functional spatial components and } \\
\text { architectural forms } \rightarrow \text { housing as a } \\
\text { sensitivefunctional entity }\end{array}$ & $\begin{array}{l}\text { Specializing in distinguishing the nature of } \\
\text { interaction/linkage between spatial elements } \\
\text { and forms } \rightarrow \text { housing as a mechanical logical } \\
\text { functional apparatus }\end{array}$ \\
\hline $\begin{array}{l}\text { Specializes in quantity of spacesections and } \\
\text { details }\end{array}$ & $\begin{array}{l}\text { Emphasis on the quality of space and } \\
\text { architectural details }\end{array}$ \\
\hline $\begin{array}{l}\text { Strong points on metaphor in architectural } \\
\text { shaping }\end{array}$ & Prone to direct realism \\
\hline $\begin{array}{l}\text { Potential for establishing organic systems in } \\
\text { living environment }\end{array}$ & $\begin{array}{l}\text { The strengths in manipulating inorganic } \\
\text { processing systems in residential environment }\end{array}$ \\
\hline $\begin{array}{l}\text { Inclining to the general consistency of } \\
\text { architectural details and functional space (high } \\
\text { incorporation) }\end{array}$ & $\begin{array}{l}\text { Appreciate the accuracy of the details of the } \\
\text { decorative and functional program (highly } \\
\text { definition) }\end{array}$ \\
\hline $\begin{array}{l}\text { "Incorporating with time": changing at the } \\
\text { same time a group of architectural elements at } \\
\text { any given time without regard to the } \\
\text { characteristic of each component (non-temporal } \\
\text { system integration) }\end{array}$ & $\begin{array}{l}\text { "Not dependent on time": thoroughly } \\
\text { transforming each functional space element and } \\
\text { architectural form only at the critical time (non- } \\
\text { time separation system) }\end{array}$ \\
\hline $\begin{array}{l}\text { Acceptance of new space elements/forms/ways } \\
\text { of organizing space by comparison with } \\
\text { objective reality (experience architecture } \\
\text { culture) }\end{array}$ & $\begin{array}{l}\text { Accepting the new space components, spatial/ } \\
\text { forms organization based on a new worldview - } \\
\text { changing space within a definite doctrine } \\
\text { (creative architectural culture) }\end{array}$ \\
\hline $\begin{array}{l}\text { Romantic emotion in space organization: } \\
\text { arranging spiritual elements wherever and } \\
\text { whenever possible according to momentary } \\
\text { feelings (decorative equipments, pottery and } \\
\text { wood vases, green plants, ... in housing space) }\end{array}$ & $\begin{array}{l}\text { Apathetic mind in establishing architecture: no } \\
\text { redundant, no lack and logical functional } \\
\text { program in space organization }\end{array}$ \\
\hline $\begin{array}{l}\text { The advantages of combining and } \\
\text { simultaneously absorbing different types of } \\
\text { housing architecture (non-professional } \\
\text { architecture culture) like a style "whatever, but } \\
\text { suitable!" }\end{array}$ & $\begin{array}{l}\text { The strengths on academic distinguishing of } \\
\text { schools of housing architecture and the types of } \\
\text { professionally functional space arrangement } \\
\text { (the professional academic architecture }\end{array}$ \\
\hline
\end{tabular}




\begin{tabular}{|l|l|}
\hline & $\begin{array}{l}\text { culture), like a style of "only "it" in the } \\
\text { conditions of "itself"” }\end{array}$ \\
\hline $\begin{array}{l}\text { The spatial organization diagram is defined by } \\
\text { nonlinear transient targets for a particular type } \\
\text { of object use (functional diagram A can be } \\
\text { transformed into B) } \rightarrow \text { the strengths on the } \\
\text { "non-linear" in housing architecture, might } \\
\text { have "unexpected changes!" }\end{array}$ & $\begin{array}{l}\text { Functional diagram is programmed in a long } \\
\text { term linear logic for a type of housing object } \\
\text { (functional diagram A can only be changed to } \\
\text { A') } \rightarrow \text { the strengths on the linearity in housing } \\
\text { architecture, based on pre-setting rules and } \\
\text { determining future development }\end{array}$ \\
\hline $\begin{array}{l}\text { High competence in imitating - copying } \\
\text { architectural components of different cultures }\end{array}$ & $\begin{array}{l}\text { Tendency to maintain and set up original } \\
\text { genuineness (voluntarism) in expression of } \\
\text { architectural form and organization of } \\
\text { architectural space }\end{array}$ \\
\hline $\begin{array}{l}\text { Quality and value of living space are assessed } \\
\text { by collective viewpoint (objectivity) }\end{array}$ & $\begin{array}{l}\text { Quality and value of living spaces are } \\
\text { determined by individual (subjectivity) }\end{array}$ \\
\hline $\begin{array}{l}\text { It is possible to vary in size, but housing with } \\
\text { similar structure for all social } \\
\text { groups(characteristic "similar" in lifestyle of } \\
\text { consumers) }\end{array}$ & $\begin{array}{l}\text { Differentiating the level of comfort and quality } \\
\text { of housing for each definite user/ social group } \\
\text { (characteristic "specialization and hierarchy" in } \\
\text { lifestyle of consumers) }\end{array}$ \\
\hline $\begin{array}{l}\text { Culture of acceptance: related to } \\
\text { combination,symbiosis, interaction, merge, } \\
\text { similar, homogenization in using spatial } \\
\text { housing }\end{array}$ & $\begin{array}{l}\text { Culture of consumption: related to aesthetic } \\
\text { needs, needs for comfort and quality, rank, } \\
\text { eliminating, new creation, market, forecast, } \\
\text { hypothesis in housing establishment }\end{array}$ \\
\hline
\end{tabular}

Table 4. Dual micro-macro culture of housing architectural systems have emerged largely in the postindustrial society era of the "global information dissemination" era (after the 1980s century XX).

\begin{tabular}{|c|c|}
\hline \multicolumn{2}{|c|}{$\begin{array}{l}\text { Housing in the era of agricultural societies, industrial societies and postindustrial (before the 1980s } \\
\text { of century XX) }\end{array}$} \\
\hline Housing architecture of micro-culture (example) & $\begin{array}{l}\text { Housing architecture of macro-culture } \\
\text { (example) }\end{array}$ \\
\hline $\begin{array}{l}\text { - Folk architecture (non-professional architecture, } \\
\text { "architecture" without architects): using experiences } \\
\text { of setting up residential spaces in order to fully adapt } \\
\text { to the external environment. } \\
\text { - Bioclimatic architecture (initiated separately } \\
\text { under the concept of "Bioclimatic regionalism" in the } \\
1960 \text { s, century XX) : architectural tendency to adapt } \\
\text { to the changing cycles of nature-climate (adaptive } \\
\text { architecture, flexible with the environment). } \\
\text { Bioclimatic architecture considers housing } \\
\text { architecture as a process (rather than a final result): } \\
\text { Climate } \rightarrow \text { Biology } \rightarrow \text { Technique } \rightarrow \text { Architecture } \rightarrow \\
\text { Users. }\end{array}$ & $\begin{array}{l}\text { - Constructivism: architecture places } \\
\text { heavy emphasis on expressing the } \\
\text { capacities and strength of the structural } \\
\text { system. } \\
\text { exists throughout the history of housing } \\
\text { architecture, (however, on the academic } \\
\text { side, this theory originates from the } \\
\text { 1960s. century XX to the present), } \\
\text { associated with the re-establishment of } \\
\text { European "social consumption" models/ } \\
\text { culture. For example: social housing } \\
\text { architecture, commercial housing } \\
\text { architecture. }\end{array}$ \\
\hline
\end{tabular}


- Bio-tech architecture: combining bio-climatic and high technological approaches to adapt to the environment ("sub-structural"), as well as changing and transforming impacts of external conditions on housing ("great -structural").

- Micro-macro multi-functional architecture, means multifunctional in all time limits and in all level (or all structures) of living space: the multifunctional "residential", "resting", "working" rooms $\rightarrow$ multifunctional residential units (apartments, single houses) $\rightarrow$ residential house in the form of unified multi-functional complex $\rightarrow$ multifunctional eco-city $\rightarrow$ multifunctional urban area, ... The micro-macro multifunctional architecture deals with two main essential problems as follows: 1) adapting at maxmium level to the actual instant needs of the user ("sub-structural"); 2) meeting the demands of further fluctuation or development in the future of the user ("great structural").

- The Neo-regionalism architecture (initiated separately, not yet set up as a unified theory system): architecture flow incorporates traditional architecture theory ("sub-structure") with advantages from the different schools of architecture (establishing the "new" in the spirit of "great - structure") to create a mix "international - local" living environment.

- Residential house as object of game of senses: using different methods and materials for form expression and space organization to serve the needs of emotion (ie architecture follows emotion. Emotion changes with the time and circumstances. Emotion is determined by the senses). Senses = continuum (sight, smell, touch, taste, hearing, extrasensory perception, ...).In other words, "Game of senses" can be considered as the consequence of the Image setting process, Contextualism and Anti-architecture (de architecture, other architecture) in urban housing.

- Housing architecture with equitable compatibility of all: 1) balance between outside - inside, all - one, collective - individual, opening - closing, dynamic - static, organic - inorganic, immaterial (spirital) - material, ...; 2) interaction between opposing space entities/ objects and different ideologies/ worldviews in establishing housing.

- Residential house as multicultural entity (multi-style, multi-school) in form expression and space organization.

- Democratic housing: activating urban residents and their insvolvement in solving their own housing problems.

- Core housing: the form of housing etablishing process, when the "core" of the building (supporting frame, ladders, engineering networks) is built by professionals, and the rest is completed by the inhabitants themselves of the house.

- Housing as metabolic autonomy in the form ofself-regulated, self-renewing and selftransformational organism.

\section{Results}

Table 5. The identification of housing architecture doctrines in the world corresponding to the microculture and macro-culture together with the results of analyzing the difference between the form of Synthetic thinking and Analytic thinking in the urban housing architecture allows establishing housing architecture system in accordance with micro-culture and macro-culture as follows.

\begin{tabular}{|l|l|}
\hline \multicolumn{1}{|c|}{$\begin{array}{c}\text { The housing architecture system that } \\
\text { corresponds to the micro-culture }\end{array}$} & $\begin{array}{c}\text { The housing architecture system that corresponds } \\
\text { to the macro-culture }\end{array}$ \\
\hline \multicolumn{2}{|c|}{ The features of the functional space arrangement thinking and the architectural forms } \\
\hline $\begin{array}{l}\text { Inclining to adapt to indigenous culture and } \\
\text { culture "community common lifestyle" } \\
\text { (collectivism): exploiting the local iconic } \\
\text { andlocal symbols in the architecture of } \\
\text { housing }\end{array}$ & $\begin{array}{l}\text { Inclining to adapt to the "individual lifestyle" } \\
\text { (individualism) culture: exploiting all elements } \\
\text { and ways of organizing any architectural space } \\
\text { that best fits the individual lifestyle }\end{array}$ \\
\hline $\begin{array}{l}\text { Flexible adaptation and maximum } \\
\text { interaction with natural-climate conditions }\end{array}$ & Improve microclimate by technique-technology \\
\hline $\begin{array}{l}\text { The tendency to establish architectural space } \\
\text { in order to adapt to users' short-term needs } \\
\text { (tactical) }\end{array}$ & $\begin{array}{l}\text { The tendency to set up architectural space to meet } \\
\text { the long-term use needs - requirements (strategic) }\end{array}$ \\
\hline
\end{tabular}


$\rightarrow$ The architecture thinking that flexibly based on flexibly adapting to external social context: the living demand-requirement arise first, leading architecture change later (the passive architecture creative thinking-tactic) Typical example. Housing architecture model in Vietnamese tradition. Demandrequirements of people in advance development shall lead to the change of organization of space that follows. For example, if the number of household members increases, it will result in more sleeping arrangements in the direction of combining these functions with other spaces in one multifunctional space or building auxiliary houses

Capacity to highly adapt and integrate different cultures in architectural thinking $\rightarrow$ It is possible to combine indigenous elements with exotic architectural elements in a unified whole in order to receive, get acquainted and move forward together For example. Neo-regionalism ofhousing architecture in Vietnam, Brazil, ... $\rightarrow$ The thinking of constantly improving and updating the exterior conditions: architecture produces needs - requirements, that means orientation architecture "goes ahead" the living needs - requirements (the active architecture creative thinking - strategy)

Typical example. The "marketing" model in housing architecture (maketing - advertising in advance of real estate products) originates from the architecture of the European housing market. The resulting housing product does not necessarily have to go through a pre-requisition of the user's needs, but in the "development prediction" direction of creating new amenities/ comfort levels and then orienting the user's habit in new living spaces

The "new" cultural creativity capacity is high in architectural thinking

$\rightarrow$ It is possible to communicate with foreign elements, but in a way that separates exotic systems from the original system into different professional doctrinal categories to compare, analyze and then learn about to upgrade to the new systems

For example. The Chicago school of sociology in architecture: separating urban spatial regions for different social groups (a model of partitioning homonymous habitat for ethnic groups, economic group, different socio-professional groups)

Highly appreciate the "spiritual culture" aspect of culture $\rightarrow$ Inclining to immaterial culture preservation. Appreciate the importance of "place spirit" and "indigenous" of living environment

Promote the "civilization" (material culture) aspect of culture

$\rightarrow$ Inclining to develop material culture. Do not put much emphasis on the location of the place of residence, only focus on the individual comfort of living environment

Housing architecture folows past and present needs/ values (traditional)

Housing architecture folows present and future needs/ values (upgrade)

Housing meets actual instant needs of the user

Flexible space structure can be changed anytime, anywhere, in order to adapt to changing needs of people and outside the environment

Multifunctional collectiveness in a unified space

Housing is to respond to the demands of further fluctuation or development in the future of the user

Spatial structure inclines to immutable immobilization in the form of "predetermined function" for each purpose or user

Apply special-purpose fixed functions for spatial components in all space levels in theform of major-additional monotonic/ great - sub monofunctional orientation

Small architectural forms, in harmony with nature, not as opposed to nature in the style of "Heaven-Earth-Human" is one ("compatibility of three elements") or harmony "Yin-Yang" ("compatibility of two elements") in a unity

Architecture of "Fragmented-multifunctional entities in a synthetic space"

$\rightarrow$ Micro-fragmented multifunction - "All in one"
The architecture of monumental and magnificent forms for "expressing power", in opposition to nature, separates the "nature-land" (natural) and the "human" into two different distinct entities

Architecture of "A united complex of specializedfunctional separative components with large scale" $\rightarrow$ Macro-complex monofunction - "All for one" 


\begin{tabular}{|l|l|}
\hline \multicolumn{2}{|c|}{ Features of the architectural space components } \\
\hline $\begin{array}{l}\text { Put emphasis on using locally-based } \\
\text { materials }\end{array}$ & $\begin{array}{l}\text { Inclining to use and create new architectural } \\
\text { materials }\end{array}$ \\
\hline $\begin{array}{l}\text { The advantage of operating organic } \\
\text { components in the living environment(trees, } \\
\text { water, natural terrain) }\end{array}$ & $\begin{array}{l}\text { Strengths of the setting up inorganic elements in } \\
\text { the living environment (statues, decorative details, } \\
\text { artificial topography) }\end{array}$ \\
\hline $\begin{array}{l}\text { Architectural-artistic objects often are } \\
\text { polysemous }\end{array}$ & Objects often are distinctive (direct meaning) \\
\hline $\begin{array}{l}\text { Put an emphasison architectural space } \\
\text { components or decorativeitems/accessories } \\
\text { that have high symbolic metaphorical and } \\
\text { symbolic spiritual meaning }\end{array}$ & $\begin{array}{l}\text { Put much emphasis on architectural space } \\
\text { components or decorative items/ accessories } \\
\text { which are likely to increase the level of individual- } \\
\text { material comfort in the residential houses }\end{array}$ \\
\hline $\begin{array}{l}\text { Prone to small architectural -artistic } \\
\text { decorative details and relativelyfunctional } \\
\text { operating details }\end{array}$ & $\begin{array}{l}\text { Prone to big overall layout of architectural- artistic } \\
\text { objects and large logical functional operating } \\
\text { program }\end{array}$ \\
\hline
\end{tabular}

Table 6. Regularities of architectural shaping in micro-, macro- and dual micro-macro culture (mesoculture) as follows.

\begin{tabular}{|c|c|c|}
\hline Micro-culture & Macro-culture & Meso-cultureof urban housing \\
\hline $\begin{array}{l}\text { Principle of mobility - } \\
\text { transformation:metabolism of } \\
\text { every housing space }\end{array}$ & $\begin{array}{l}\text { Principle of } \\
\text { differentiation and } \\
\text { specialization of } \\
\text { space function: } \\
\text { specific appellation } \\
\text { and purpose of each } \\
\text { housing space }\end{array}$ & $\begin{array}{l}\text { - Principle of metabolic autonomy } \\
\text { - Principle of removal - addition } \\
\text { (Mini - max principle): attainment of } \\
\text { maximum efficiency of spatial } \\
\text { elements by replacing different } \\
\text { functional spaces in the same total } \\
\text { area of housing in general }\end{array}$ \\
\hline $\begin{array}{l}\text { Principle of direction: spatial } \\
\text { orientation in order to maximize } \\
\text { the use of favorable factors or } \\
\text { protect housing from sources of } \\
\text { unfavorable factors }\end{array}$ & $\begin{array}{l}\text { Principle of } \\
\text { hierarchy: discipline, } \\
\text { main - minor, great - } \\
\text { sub, before - after, } \\
\text { lower - higher, major } \\
\text {-additional, ... }\end{array}$ & $\begin{array}{l}\text { Principle of unchangeability - } \\
\text { housing as structure of organism: 1) } \\
\text { technical - structural elements as } \\
\text { skeleton (fixed); 2) communicative } \\
\text { space elements as blood vessels } \\
\text { (linked); } 3 \text { ) variable spatial elements } \\
\text { as tissue - shell (metabolic) }\end{array}$ \\
\hline $\begin{array}{l}\text { Principle of adaptation (passive } \\
\text { housing architecture): housing } \\
\text { architecturefollows natural and } \\
\text { social environment }\end{array}$ & $\begin{array}{l}\text { Principle of exception } \\
\text { (active housing } \\
\text { architecture): housing } \\
\text { architecture follows } \\
\text { subject's worldview }\end{array}$ & $\begin{array}{l}\text { Principle of contextualism and image } \\
\text { setting: housing architecture as } \\
\text { interactional entity of } \\
\text { environment }+ \text { senses of consumer } \\
\text { (senses of subject/ user)+ information }\end{array}$ \\
\hline $\begin{array}{l}\text { Principle of dispersal: multi- } \\
\text { functional entities of same } \\
\text { functions }\end{array}$ & $\begin{array}{l}\text { Principle of } \\
\text { centralization: } \\
\text { monotonous center of } \\
\text { major functions }\end{array}$ & $\begin{array}{l}\text { Principle of decentralization and } \\
\text { megastructure: multi center of multi- } \\
\text { function with "unlimited" extension } \\
\text { of connecting architectural objects }\end{array}$ \\
\hline $\begin{array}{l}\text { Principle of nonlinear: } \\
\text { undefined }\end{array}$ & $\begin{array}{l}\text { Principle of linear: } \\
\text { always pre-defined or } \\
\text { pre-forecasts of } \\
\text { development }\end{array}$ & $\begin{array}{l}\text { Principle of "super-linear"(in future } \\
\text { (guess)): random in the definition and } \\
\text { vice versa, chaos in the order and vice } \\
\text { versa, law of lawlessness, ... }\end{array}$ \\
\hline $\begin{array}{l}\text { Principle of "spiritual field of } \\
\text { place and time": tradition and } \\
\text { culture as fundamental } \\
\text { conditions of establishing } \\
\text { housing }\end{array}$ & $\begin{array}{l}\text { Principle of "field of } \\
\text { comfort level": varied } \\
\text { quality for different } \\
\text { customers as major } \\
\text { factor in establishing } \\
\text { housing }\end{array}$ & $\begin{array}{l}\text { - Principle of "field of varied } \\
\text { impulse"("field of impulsive way of } \\
\text { life"): infinitely developmental } \\
\text { multi-personal lifestyle of "Flat } \\
\text { world" as prerequisite in establishing } \\
\text { housing } \\
\text { • Principle "architectural-artistic } \\
\text { object as field" }\end{array}$ \\
\hline
\end{tabular}




\begin{tabular}{|c|c|c|}
\hline $\begin{array}{l}\text { Principle "from outside to } \\
\text { inside": environment(natural } \\
\text { and social) } \rightarrow \text { exterior/ form of } \\
\text { housing } \rightarrow \text { interior/ content of } \\
\text { housing } \rightarrow \text { dweller }\end{array}$ & $\begin{array}{l}\text { Principle "from inside } \\
\text { to outside": dweller } \\
\text { (personal need, } \\
\text { consumption, } \\
\text { character) } \rightarrow \\
\text { structure of housing } \\
\rightarrow \text { environment }\end{array}$ & $\begin{array}{l}\text { - Principle of continuity - integrity: } \\
\text { unified system "dweller - housing - } \\
\text { environment" as fair interaction of } \\
\text { three distinct entities } \\
\text { - Principle of equitable } \\
\text { compatibility of all } \\
\text { - Principle of opposing } \\
\text { interactionism }\end{array}$ \\
\hline $\begin{array}{l}\text { Principle of polysemy: } \\
\text { an architectural object has many } \\
\text { meanings and functions }\end{array}$ & $\begin{array}{l}\text { Principle of } \\
\text { genuineness:an } \\
\text { architecture object } \\
\text { has only one meaning } \\
\text { and function for itself }\end{array}$ & $\begin{array}{l}\text { Principle of hybridity and fractality: a } \\
\text { cross between housing architectural } \\
\text { cultures in architectural object }+ \\
\text { housing structure as approximation of } \\
\text { the shape/ meaning of the various } \\
\text { sized objects }\end{array}$ \\
\hline $\begin{array}{l}\text { Principle of } \\
\text { naturalistism:multiplicity, } \\
\text { diversity, harmony, mimicry, } \\
\text { metabolism, freedom } \\
\text { adaptability,variability, self- } \\
\text { regulated, self-healing, "green", } \\
\text { reproduction, symbiosis, } \\
\text { energy exchanges, heredity }\end{array}$ & $\begin{array}{l}\text { Principle of } \\
\text { consumerism: } \\
\text { profitableness, } \\
\text { quality,housing } \\
\text { market, hierarchy } \\
\text { (level and order) of } \\
\text { needs, cultural and } \\
\text { consumer standard, } \\
\text { housing standard, } \\
\text { classification of } \\
\text { housing, }\end{array}$ & $\begin{array}{l}\text { Principle of } \\
\text { ecology:transformability,mobility, } \\
\text { metabolism, autonomy, bio- } \\
\text { physiological comfort, social comfort } \\
\text { (individual, group, collective comfort } \\
\text { of social communicative interaction), } \\
\text { contextuality, renewability, } \\
\text { continuity, efficiency, } \\
\text { multilayeredness, independence, self- } \\
\text { governing, autoregulation, automatic, } \\
\text { auto artificial intelligence, "green", } \\
\text { health }\end{array}$ \\
\hline $\begin{array}{l}\text { Principle of collectivism: } \\
\text { formation of housing } \\
\text { architecture follows collective } \\
\text { worldviews }\end{array}$ & $\begin{array}{l}\text { Principle of } \\
\text { individualism: } \\
\text { individual "Ego" } \\
\text { conditions as major } \\
\text { factor in establishing } \\
\text { housing }\end{array}$ & $\begin{array}{l}\text { Principle of objective individualism: } \\
\text { establishing individual spaces and } \\
\text { forms with taking into account the } \\
\text { collective/ common demands for use } \\
\text { (relationship between individualism } \\
\text { and collectivism) }\end{array}$ \\
\hline $\begin{array}{l}\text { Principle of metaphor: } \\
\text { architectural forms with indirect } \\
\text { meaning (deductive reasoning) }\end{array}$ & $\begin{array}{l}\text { Principle of realism: } \\
\text { direct expressing of } \\
\text { architectural object's } \\
\text { original meaning }\end{array}$ & $\begin{array}{l}\text { Principle of interactionism of things- } \\
\text { in-themselves:house as interactional } \\
\text { entity of housing's meaning-in-itself } \\
\text { and user's cognition-in-itself }\end{array}$ \\
\hline $\begin{array}{l}\text { Principle of } \\
\text { traditionalization:symbolization, } \\
\text { sensitivity, copy, similar, } \\
\text { common ideologies of } \\
\text { community, integration, past } \\
\text { and present, spiritual meaning, } \\
\text { heredity, lifestyle of family and } \\
\text { community, local typology, } \\
\text { local material and method }\end{array}$ & $\begin{array}{l}\text { Principle of } \\
\text { professionalism: } \\
\text { rationality, logic, } \\
\text { precision, } \\
\text { specialization, school, } \\
\text { level, segregation, } \\
\text { rule, condition, role, } \\
\text { function, } \\
\text { meaning,system, } \\
\text { structure,paradigm, } \\
\text { model, program, } \\
\text { principle, legitimacy, } \\
\text { regularity, trend }\end{array}$ & $\begin{array}{l}\text { Principle of democratization.Housing } \\
\text { organization is based on: justness in } \\
\text { accordance with the inherent nature } \\
\text { of all objects and subjects, behavior/ } \\
\text { personality/ individualityin structure } \\
\text { of living space,clear division, } \\
\text { common utilities of individual and } \\
\text { community, complicity in solving } \\
\text { housing problems by habitants } \\
\text { themselves, freedom by rules, self- } \\
\text { control, self-service, lifestyle of } \\
\text { subjects/ users }\end{array}$ \\
\hline
\end{tabular}

From the tables (1-6), it is possible to determine the appearance frequencies of Microculture and Macro -culture that corresponds to the paradigms of social knowledge in urban housing architecture as follows (Fig. 2). 


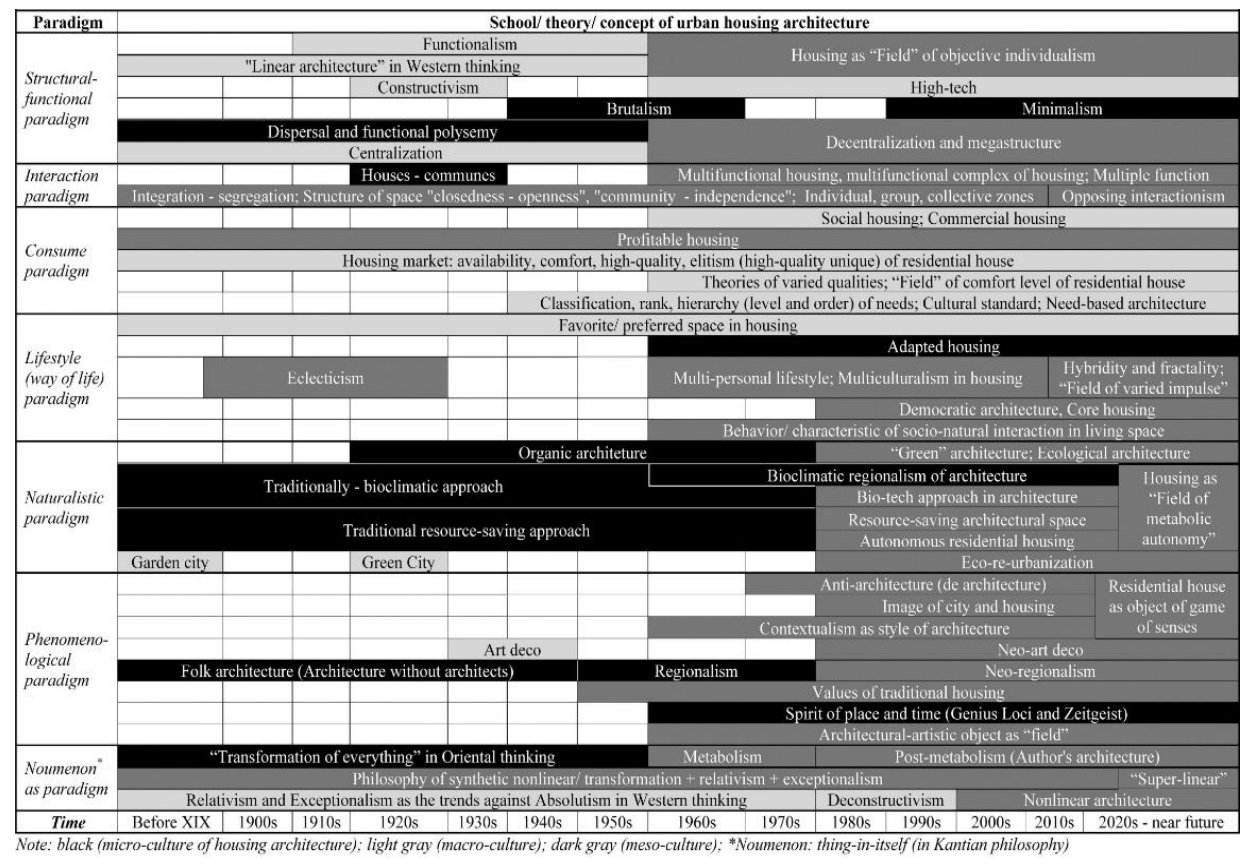

\section{Discussion}

Micro-culture or "sub-structure"(micro-structure) culture can be considered as one of the orthodox traditional cultural stereotypes of the East. However, in the process of East-West cultural interaction and inland between different cultures in the postmodern period, Oriental culture is introduced by some features of the "great structure" (macro-structure) aiming at adapting or developing integration. As the reception of "great-structure" culture originates from the outside so it can be considered to be the type of non-formal interaction of Oriental culture.

The sub-structure and great-structure, as well as micro-culture and macro-culture, are two opposite states of the human being and original socio-natural system. The future development trends of urban housing architecture in the world depend largely on the interplay between these two cultural universes. If too inclining to micro-structure and micro process, architecture is generally difficult to develop into high levels of complicated,systemic, or revolutionary rationality. However, if too much emphasis is put on the macro-structure or macro process, then the level of skill of subtlety,finesse and agilityas well as the maneuverability in order to adapt stably to the modes of architectural interactions is reduced.

Great revolutionary architectural tendencies of Western architectural science throughout the twentieth century to transform the face of human civilization haved contributed significantly to the search for and the establishment of new forms of living space. For example: the Functionalism of 1920s, the High technical architecture of 1960s etc. However, these architectural revolutions were quickly abolished and replaced by new trends, or combined with different approachs in the form of new schools. The reason: almost all of these architectural revolutions or tendencies, in essence, are inadequate to meet social needsrequirements and the internal constantly changing bio-physiological demands (belonging to substructural characteristics) of the users/ residents in particular and any overall society in general.It is therefore not accidental that, from the 1980s of centure XX to the present (of the postindustrial society era), Western architectural science, objectively, has begun to shift to incorporating the microadapting mobility of "micro-structure" in the overall "great-structure" 
to adapt to the rapidly changing dynamics within the structural socio-natural systems of the human being. For example, the trends of Neo-regionalism, Post-metabolism, and Bio-tech architecture are all very characteristic of micro-culture originating from Asian ideologies. This also reflects an important tendency: any doctrine/ school of architecture can self-adjust and upgrade to a binary micro-macro variant. The combination of "micro-macro" in housing architecture addresses two major issues: 1) ensure the stability of large systems before any change from the inside (self-transforming) or from the outside (altering the external environment) and minimizing the risks (crisis) that are possible to the large system, by applying the "sub-structure" cultural identity in all socio-natural interaction in general and the housing architecture in particular; 2) continually reform and update large systems to new levels of sophistication or new revolution, that is, to promote the cultural-social interaction of "great structure".

Thus, "great-structure" is the decisive factor for development and the driving force behind the establishment of technological and technical revolutions in general and housing architecture in particular; and "sub-structure" is the key factor in maintaining adaptive stability for newly established systems. The "stabilization-development" duality of the "subgreat structure" system corresponds to the category of "micro-macro culture" which reflects the school of thought "Social statics", representing the balance of a perfect society and "Social dynamics" - characterized by the process of development and the creative capacity of human society.

\section{Conclusions}

In conclusion, based on the analysis and comparison of the formal characteristics and the method of organization of urban space architecture in two types of micro-culture and macroculture can be identified as follows.

1. Micro-architecture culture of the East with main characteristics in the form of original code - attribute as follows: 1) culture of acceptance, 2) quantity, 3) adaptive, 4) mobility (metabolic) - process, 5) polysemy, 6) fusion (passive integration), 7) harmonic, 8) organic, 9) chaos (promiscuity), 10) similar, 11) synthetic, 12) "all in one"/ "one for all", 13) collective, 14) micro-fragmented relative multifunction, 15) sensitive functional entity, 16) relativelyfunctional operating details, 17) small scale, 18) small details, 19) stable, 20) passive - experience, 21) tactics (for a short term), 22) nonlinear/ relativism, 23) mimicry copy, 24) spiritual comfort, 25) past and present (traditionalization), 26) indirect - metaphor and hiding, 27) romantic emotion, 28) objectivity, 29) "from outside to inside", 30) open.

2. Macro-architecture culture of the West with features in the form of code as follows: 1) culture of consumption, 2) quality, 3) conservative, 4) fixed - result, 5) genuineness,6) active segregation, 7) main - minor and specialization, 8) inorganic, 9) discipline (rule), 10) level, 11) analytic, 12) "one and all the rest"/ "all for one", 13) individual, 14) macro-complex specialized monofunction, 15) mechanical logical functional apparatus, 16) lagre rational functional operating program, 17) large aperture, 18) big overall layout, 19) development, 20) active - creative, 21) strategy (for a long term), 22) linear/ absolutism, 23) genuineness voluntarism, 24) material comfort, 25) present and future (upgrade), 26) direct - realism and expression, 27) apathetic mind, 28) subjectivity, 29) "from inside to outside", 30) closed.

3. Meso-architecture culture with major concepts: 1) Bio-organism, 2) ecology, 3) field of metabolic autonomy, 4) field of varied impulse, 5) decentralization and megastructure, 6) multifunction in all space levels and in all time limits, 7) information, 8) values and meaning, 9) context, 10) image and sign, 11) game of senses, 12) multi-personal lifestyle, 13) multiculturalism,14) objective individualism, 15) democratization, 16) phenomenon and noumenon,17) "super-linear", 18) equitable compatibility of all, 19) interactionism of thingsin-themselves, 20)hybridity and fractality. 
4. Almost all of the dual micro-macro (meso)architectural cultures began to appear in the 1960s of century XX and thrive after the "information boom" stage (from the 1980s of century XX up to now). The meso-architecture culture is considered as a self-transforming result of any architectural tendency in the self-regulating process, in line with the regular mobility of urban lifestyles in the "flat world". This is one of the most major trends of urban housing architecture in the world in the post-industrial social information era (Fig. 3).

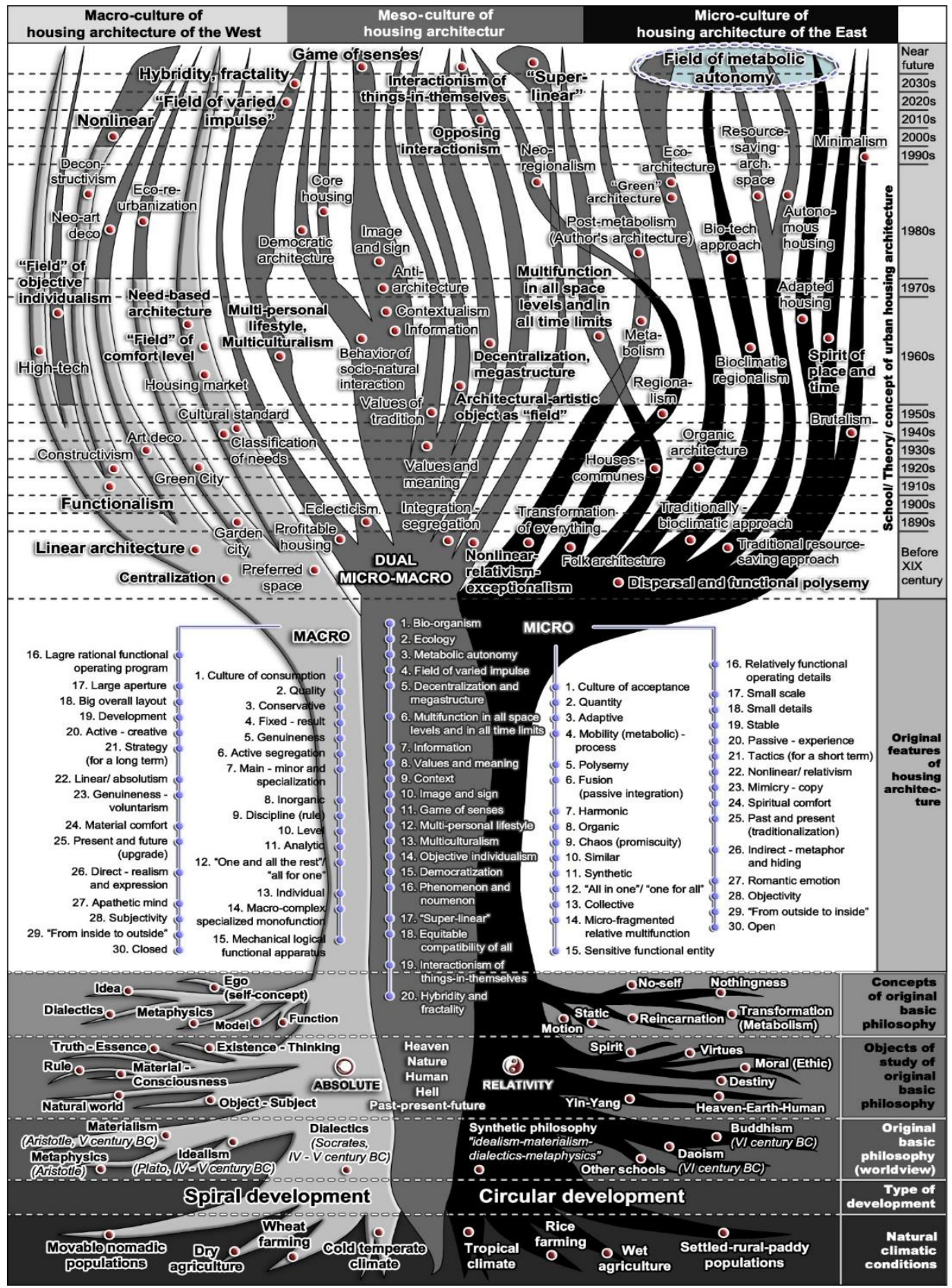

Fig. 3. One of the major trends of urban housing architecture in the world in the post-industrial social information era. 


\section{References}

1. L.Yu. Anisimov, Principles of architectural formation of adapted housing (MARCHI, Moscow, 2009)

2. R.G. Arakelian, Improvement of quality ofresidential environment, taking into account values of traditional residential units (on the example of Armenian Highland) (MARCHI, Moscow, 2011)

3. K.V. Burlakov, Features of topological form-building in foreign architecture of turn 20th and 21st centuries, the summary of the Ph.D thesis in architecture: 05.23 .20 (N. Novgorod, 2011)

4. M.M. Dadasheva, The artistic language of architecture of the end XX -the beginning XXI century in categories of volume spatial composition, summary of Ph.D thesis in architecture: 05.23.20 (MARCHI, Moscow, 2016)

5. E.V. Denisenko, Principles for formation of architectural space based on bioapproaches, summary of Ph.D thesis in architecture: 05.23.20 (N. Novgorod, 2013)

6. I.A. Dobritsyna, From postmodernism to nonlinear architecture: Architecture in context of modern philosophy and science (Progress - Tradition, Moscow, 2004)

7. M.V. Dutsev, Concept of artistic integration in newest architecture, the summary of the Grand Ph.D thesis in architecture: 05.23.20 (N. Novgorod, 2014)

8. I.G. Fedchenko, Formation of residential planning units in the middle of the $X X$ - the beginning of the XXI century, summary of Ph.D thesis in architecture: 05.23.22 (Krasnoyarsk, 2016)

9. A.V. Ikonnikov, Architecture of XX century. Utopia and Reality, Volume II (Progress Tradition, Moscow, 2002)

10. K.V. Kiyanenko, Architecture and social modeling of housing, summary of Grand Ph.D thesis in architecture: 18.00.02 (MARCHI, Moscow, 2005)

11. D.A. Kulikov, Principles of organization of resource-saving architectural space, summary of Ph.D thesis in architecture: 05.23 .20 (N. Novgorod, 2011)

12. V.M. Molchanov, Planning, architecture, art and design, Abstracts of international scientific - practical conference, Rostov-on-Don: Institute of architecture and arts, 206 209 (2009)

13. O.V. Orelskaia, Modern foreign architecture, Reference materials for students at tertiary institutions (Publishing Center "Academy", Moscow, 2006)

14. P.V. Pipunyrov, Evolution of low-rise housing architecture in the aspect of bioclimatic approach to design, summary of Ph.D thesis in architecture: 05.23.20 (N. Novgorod, 2011)

15. A.O. Pogonin, Principles of formation of autonomous residential buildings in extreme natural conditions, summary of Ph.D thesis in architecture: 05.23.21 (MARCHI, Moscow, 2010)

16. P.A. Putintsev, Design in formation of image of city, summary of Ph.D thesis in art history: 17.00.06 (Ekaterinburg, 2011)

17. L.V. Savelyeva, Visual illusions in architectural composition, summary of Ph.D thesis in architecture: 05.23.20 (MARCHI, Moscow, 2016)

18. G.V. Vershinin, Context in architecture, design, art of the XX century, summary of Ph.D thesis in art history: 17.00.04 (Ekaterinburg, 2005) 
19. A.V. Voronina, Principles of "eco-re-urbanization" in architectural space of postindustrial development, summary of Ph.D thesis in architecture: 05.23.20 (N. Novgorod, 2012)

20. K.O. Vytuleva, Spatial experiments in the newest architecture (for the question of "new images"), summary of Ph.D thesis in art history: 17.00.04 (MGU named by M.V. Lomonosov, Moscow, 2010)

21. A.A. Zaitsev, Contextualism as a stylistic trend in architecture of late XX-early XXI centuries, summary of Ph.D thesis in architecture: 05.23.20 (N. Novgorod, 2013)

22. A.Yu. Zaslavskaia, Features of organic approach in architecture of late twentieth-early twenty-first century, summary of Ph.D thesis in architecture: 18.00.01 (N. Novgorod, 2008)

23. I.V. Zhdanova, Architectural methods for assessing and improving the consumer properties of residential environments, summary of Ph.D thesis in architecture: 05.23.21 (N. Novgorod, 2013)

24. S. H. Nguyen, Characteristics of traditional culture exploitation in residential architecture in big cities of Vietnam, Doctoral thesis of architecture: 62.58.01.02 (HCM city, 2016)

25. N. T. Tran, Find out about Vietnamese cultural identity (General publisher, Ho Chi Minh city, 2006) 